\title{
QUALITATIVE ASSESSMENT OF GROUNDWATER IN SINGRAULI COALFIELD REGION, MADHYA PRADESH
}

\author{
A. K. Sonkar and A. Jamal \\ Department of Mining Engineering, \\ Indian Institute of Technology (Banaras Hindu University), Varanasi-221005, India \\ *E-mail : ashwanijack@gmail.com
}

\begin{abstract}
Singrauli coalfield is mostly affected by active mining industries. The objective of this paper is to assess the impact of mining activities on groundwater quality in Singrauli Coalfield area of Madhya Pradesh. The present study aims are determining the groundwater quality Index in Singrauli Coalfield region. Six groundwater samples were collected from the wells \& hand pump located in the study area and analyzed for hydro-chemical characteristics such as $\mathrm{pH}$, electrical conductivity, total dissolved solids, Hardness, Dissolved oxygen,Calcium, Magnesium, Sodium, Bicarbonate, Chlorides, Sulphate, and Iron. The obtained results were compared with ISI (Indian Standard Institution) and WHO (World Health Organization) standards for drinking water. The results indicate that groundwater was more affected by coal mines. Global Positioning System (GPS) was used to identify the sample location.
\end{abstract}

Keywords: Water Quality Index (WQI), Physico-chemical parameters, Groundwater, Coalmines.

() RASĀYAN. All rights reserved

\section{INTRODUCTION}

Singrauli district of Indian state of Madhya Pradesh emerging as India's Energy capital covered by open cast coal mine, electricity generation power plants, and dense forests. The availability of water by exterior and groundwater resources has become serious. This section deals with the water quality of tube wells and dug wells with special reference to the suitability of water for drinking purpose. Mining activity significantly affects the local environmental system in various ways, including land subsidence, lowering the groundwater table, Ground and Surface water quality and mine gas emissions. Open cast coal mining activities disturb the hydro-geological system and result in physical, chemical and environmental changes often resulting in pollution of both surface and groundwater. The major impact of open cast coal mining is degradation in the water quality due to acid mine drainage, toxic pollutants and change in hydrology and disturbance in groundwater table which results into lowering of groundwater table leading to a reduced yield of water from the bore-wells. Provision of groundwater for drinking purpose under desirable limit suggested by standards is mandatory. ${ }^{13}$ GPS techniques are used to identify the location of the earth surface features. GIS is used to incorporate the GPS location information and to do further analysis. The water quality index of the study area is essential to understand the quality of water in that area.

\section{Study Area}

The study area lies partly in Singrauli district of Madhya Pradesh and partly in Sonebhadra district of Uttar Pradesh. The Singrauli coalfield lies between $24^{\circ} 00^{\prime} \mathrm{N}$ to $24^{\circ} 15^{\prime} \mathrm{N}$ latitude and $82^{\circ} 30^{\prime} \mathrm{E}$ to $82^{\circ} 45^{\prime} \mathrm{E}$ longitude. The coal reserves in the north-eastern part of Singrauli coalfield and the total area of the coal field is $2201 \mathrm{~km} 2$, however, at present, only $300 \mathrm{~km} 2$ area is exploited for coal. With the availability of power grade coal reserves and the nearby Govind Ballabh Pant, Sagar reservoir offers an excellent location for super thermal power plants (STPS). The area is occupied by structural hills on the northern part with elevation ranging between $280 \mathrm{~m}-610 \mathrm{~m}$. There are eleven mining blocks of which Kakri, Bina, Marrak, and part of Khadia and Dudhichua are in Uttar Pradesh whereas Jhingurda, Gorbi, Moher,

Rasayan J. Chem., 11(3), 1270-1276(2018)

http://dx.doi.org/10.31788/RJC.2018.1134026

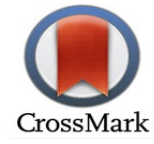


Amlohri, Nigahi, Jayant and parts of Khadia and Dudhichua are in Madhya Pradesh. Location map of the study area is shown in Fig-1.

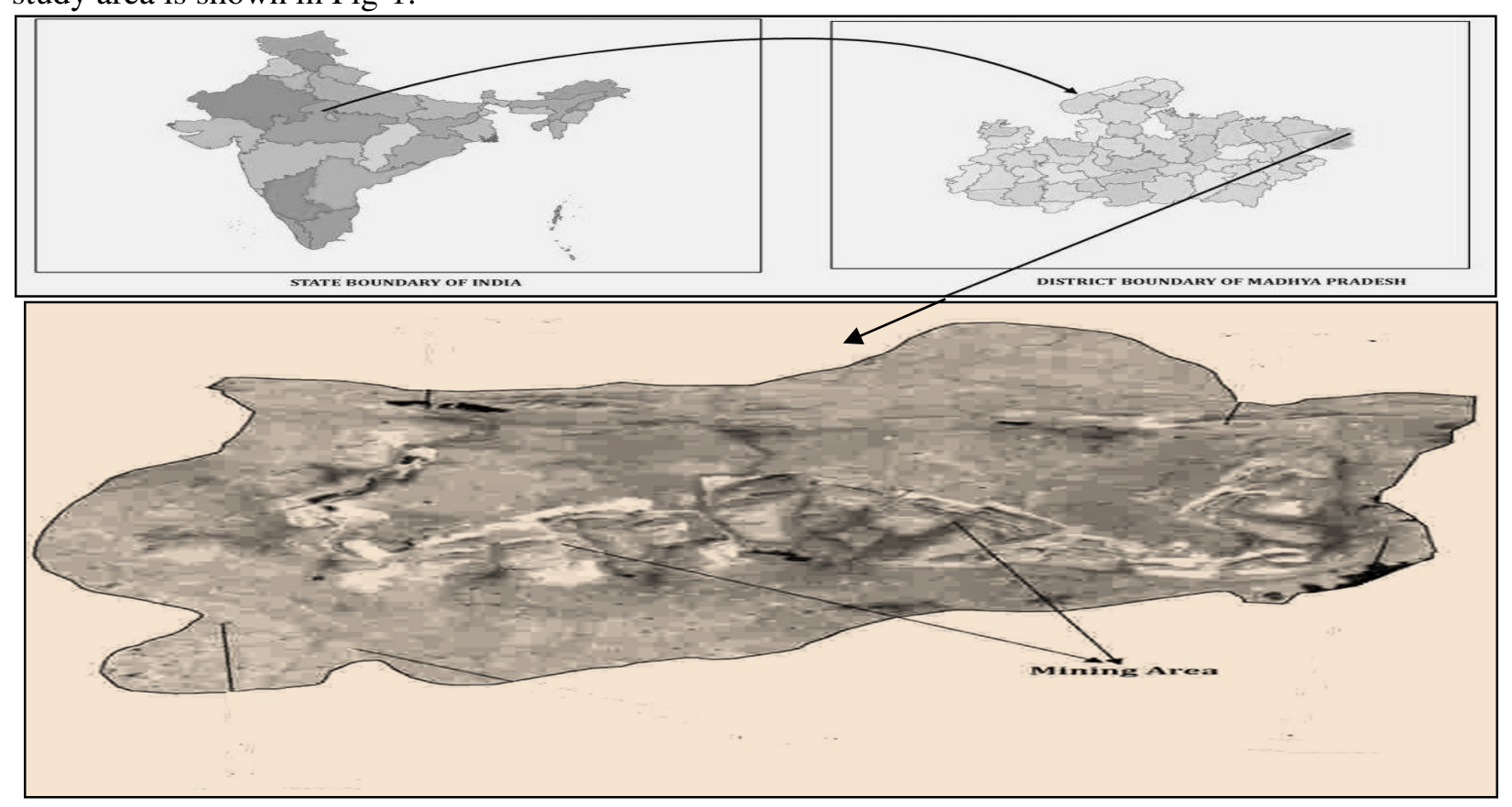

Fig.-1: Location map of the study area

\section{Material and Methods}

\section{EXPERIMENTAL}

Groundwater samples were collected from the hand-pumps and Dug-well of 6 villages of Singrauli coalfield region in 2018(Fig.3).Samples were collected in clean polythene bottles pre-washed with dilute hydrochloric acid and rinsed three to four times with the water samples before the samples were stored at a temperature below $4^{0} \mathrm{c}$ prior to analysis in the laboratory.

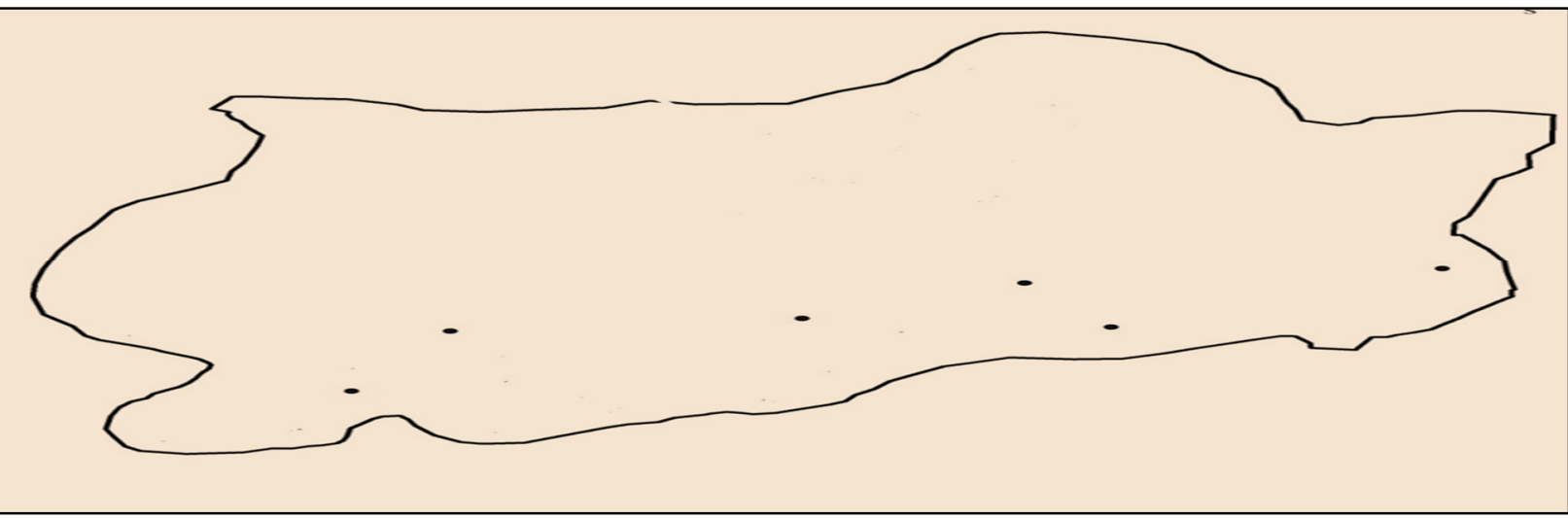

Fig.-2: Sample Location Map of the study area

The parameters $\mathrm{pH}$, electrical conductivity and dissolved oxygen were monitored at the sampling site and other parameters like total dissolved solids, hardness, dissolved oxygen, calcium, magnesium, Sodium, Bicarbonate, chloride, sulphate and Iron were analyses in the laboratory as per the standard procedures of APHA (1995). Sample locations map was prepared by using Arc GIS software are shown in Fig-2.

In this study, for the calculation of water quality index of groundwater, twelve important parameters were chosen. The WQI has been calculated by using the Arithmetic Index Method. Standards of drinking water quality recommended by the World Health Organization (WHO) and Bureau of Indian Standards 
RASĀYAN J. Chem.

Vol. 11 | No. 3 |1270 - 1276 | July - September | 2018

(BIS).The weighted Arithmetic Index Method has been used for the calculation of WQI of the ground water by using the following equation.

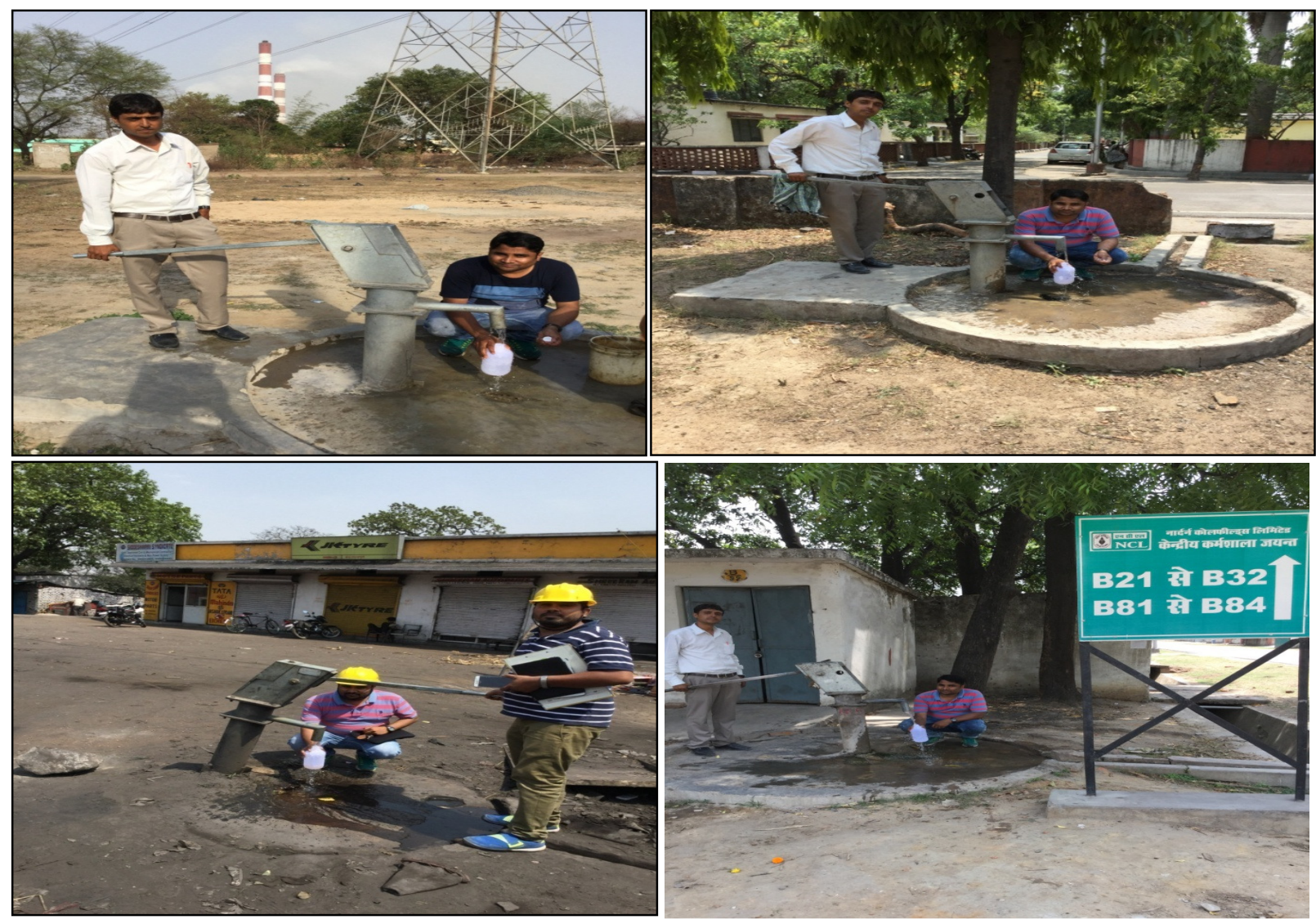

Fig.-3: Water sampling of the study area

Water Quality Index (WQI) was calculated by aggregating the quality rating with the unit weight linearly.

$$
\mathrm{WQI}=\sum q_{n} W_{n} / \sum W_{n}
$$

Where, $\quad q_{n} \quad=100\left[V_{n}-V_{i o}\right] /\left[S_{n}-V_{i o}\right]=$ sub index

$W n=\mathrm{k} / S_{n}=$ unit weight for the $n^{\text {th }}$ parameters.

$S_{n} \quad=$ Standard value for $n^{\text {th }}$ parameters

$\mathrm{K}=\mathrm{k}=1 / \Sigma 1 / S_{n}=$ Constant for proportionality

Table-1: Water quality classification based on WQI ${ }^{11}$

\begin{tabular}{c|c}
\hline WQI & Status \\
\hline $0-25$ & Very Good \\
\hline $25-50$ & Good \\
\hline $50-70$ & Poor \\
\hline$>70$ & Very Poor \\
\hline
\end{tabular}

\section{RESULTS AND DISCUSSION}

The laboratory result of the collected groundwater samples has been shown in Table-2. The test result was compared with the standards (WHO/BIS) for drinking water. It is mandatory to monitor the drinking water for healthy life ${ }^{5}$. Six sample of groundwater is denoted by GW-1,2,3,4,5 and 6 shown in Table$2 \& 3$.The Physico-chemical result of groundwater is shown in Table- 2 . 
RASĀYAN J. Chem.

Vol. 11 | No. 3 |1270 - 1276 | July - September | 2018

Table-2: Physico-chemical parameters of the groundwater of Singrauli coalfield

\begin{tabular}{c|c|c|c|c|c|c|c|c}
\hline $\begin{array}{c}\text { Sample } \\
\text { Location }\end{array}$ & GW-1 & GW-2 & GW-3 & GW-4 & GW-5 & GW-6 & Standard & $\begin{array}{c}\text { Recommended } \\
\text { agency }\end{array}$ \\
\cline { 1 - 6 } Parameter & & & & & & & & \\
\hline pH & 7.9 & 8.35 & 8.32 & 8.4 & 8.34 & 8.4 & $6.5-8.5$ & BIS/WHO \\
\hline TDS & 872 & 942 & 1646 & 1420 & 932 & 682 & 500 & BIS/WHO \\
\hline EC & 284 & 298 & 462 & 454 & 262 & 223 & 300 & BIS/WHO \\
\hline Hardness & 132 & 124 & 106 & 72 & 142 & 123 & 300 & BIS/WHO \\
\hline DO & 4.5 & 5.1 & 4.9 & 5.3 & 5.8 & 4.9 & 5.00 & BIS/WHO \\
\hline Calcium & 21.82 & 18.36 & 43.63 & 21.38 & 26.48 & 29.48 & 75 & BIS/WHO \\
\hline Magnesium & 16.84 & 17.34 & 3.8 & 3.32 & 19.32 & 12.56 & 30 & BIS/WHO \\
\hline Sodium & 81.5 & 107.5 & 162 & 182 & 107.5 & 78 & 200 & BIS/WHO \\
\hline Bicarbonate & 424 & 314 & 592 & 432 & 474 & 382 & 200 & BIS/WHO \\
\hline Chlorides & 602.6 & 472 & 1282 & 462 & 382 & 493.8 & 250 & BIS/WHO \\
\hline Sulphate & 15.28 & 28.56 & 117.32 & 62.24 & 30.48 & 8.56 & 150 & BIS/WHO \\
\hline Iron & 0.564 & 0.209 & 0.042 & 0.152 & 0.112 & 0.067 & 0.3 & BIS/WHO \\
\hline
\end{tabular}

All parameters are given in $\mathrm{mg} / \mathrm{L}$, excluding $\mathrm{pH}$ and Electrical conductivity $(\mu \mathrm{S} / \mathrm{cm})$

pH

$\mathrm{pH}$ is a quantitative measure of the acidity or basicity of water solution. The minimum and maximum allowable limit for $\mathrm{pH}$ in drinking water are 6.5-8.5 respectively. The $\mathrm{pH}$ values of the Groundwater samples vary from 7.9 to 8.4 .

\section{Total Dissolved Solids (TDS)}

Total Dissolved Solids represents the total concentration of dissolved substances in water. The concentration of TDS in the groundwater sample varies from 682 to $1646 \mathrm{mg} / \mathrm{L}$ in the study area. Sample No.3 is highest TDS.(Table-2).

\section{Electrical Conductivity (EC)}

Conductivity is the capacity of water to carry an electrical current and varies both with number and types of ions the solution contains. This conductivity depends on the presence of ions in their total concentration, mobility, valence and relative concentration and on the temperature of the liquid. The Electrical Conductivity of the study area varies from 223 to $462 \mu \mathrm{S} / \mathrm{cm}$.

\section{Hardness}

The concentration of hardness of groundwater sample ranges from (72-142) $\mathrm{mg} / \mathrm{L}$. The acceptable limit of Hardness is (500-1500) $\mathrm{mg} / \mathrm{L}$ as per (WHO) recommendations. Hardness in water is caused primarily by the presence of carbonates and bicarbonates of calcium and magnesium, as well as due to sulfates, chlorides, and nitrates.

\section{Dissolved oxygen (DO)}

The concentration of Dissolved oxygen of groundwater sample ranges (4.5-5.3) $\mathrm{mg} / \mathrm{L}$.

\section{Calcium $\left(\mathbf{C a}^{++}\right)$}

The concentration of calcium ion of groundwater sample ranges (18-44) $\mathrm{mg} / \mathrm{L}$. The acceptable limit of calcium is $(75-200) \mathrm{mg} / \mathrm{L}$, as per (WHO) recommendations.

\section{Magnesium $\left(\mathrm{Mg}^{2+}\right)$}

The concentration of Magnesium ion of groundwater sample ranges (3-18) $\mathrm{mg} / \mathrm{L}$. The permissible limit of magnesium is (30-150) $\mathrm{mg} / \mathrm{L}$.

\section{Sodium $\left(\mathrm{Na}^{+}\right)$}

The concentration of Sodium ion of groundwater sample ranges $(78-182) \mathrm{mg} / \mathrm{L}$. The permissible limit of magnesium is $70 \mathrm{mg} / \mathrm{L}$. 
RASĀYAN J. Chem.

Vol. 11 | No. 3 |1270 - 1276 | July - September | 2018

Bicarbonate $\left(\mathrm{HCO}^{-3}\right)$

The concentration of Bicarbonate of groundwater sample ranges (382-592) $\mathrm{mg} / \mathrm{L}$. The permissible limit of magnesium is $600 \mathrm{mg} / \mathrm{L}$.

\section{Chlorides $\left(\mathrm{Cl}^{-}\right)$}

Chloride is the most important parameter in assessing the water quality and higher concentration of chloride indicates a higher degree of organic pollution. According to BIS/ICMR the permissible limit of chloride in drinking water is $250 \mathrm{mg} / \mathrm{l}$. The concentration of Chlorides ion of groundwater sample ranges (78-182) $\mathrm{mg} / \mathrm{L}$. The Concentrations of chloride in natural water resources depend on geochemical conditions and vary from sites to sites. All values are lies within the acceptable limit. ${ }^{8}$

\section{Sulphate $\left(\mathrm{SO}_{4}^{-3}\right)$}

The concentration of Sulphate of groundwater sample ranges $(9-118) \mathrm{mg} / \mathrm{L}$. as per BIS the desirable level is $200 \mathrm{mg} / \mathrm{L}$.

\section{Iron}

The concentration of Iron in the groundwater sample ranges $(0.042-0.564) \mathrm{mg} / \mathrm{L}$. The accepted limit of iron is $(0.1-0.3) \mathrm{mg} / \mathrm{L} .^{3}$

\section{Water Quality Index}

The water quality index results are used to determine the suitability of water for drinking purposes. Water quality identification is important to full fill the requirement of drinking water in towns ${ }^{10}$. Table- 3 shows the water quality index (WQI) of six groundwater samples of the study area. WQI values greater than 100 of groundwater station (GW-1) are not suitable for human utilization without suitable treatment. Water quality index of groundwater station GW-2 \& GW-4 is greater than 50 and it is poor quality.WQI value is less than 50 of groundwater station GW-3 \& GW-5 and which is suitable for drinking purpose.

Table-3: Calculation of sub-indices and WQI of the groundwater samples

\begin{tabular}{|c|c|c|c|c|c|c|}
\hline Sample Location & & & & & & \\
\hline Parameter $\left(\mathrm{Q}_{\mathrm{I}} \mathrm{W}_{\mathrm{I}}\right)$ & GW- 1 & $G W-2$ & GW-3 & GW-4 & GW-5 & GW-6 \\
\hline $\mathrm{pH} \mathrm{Q}_{\mathrm{I}} \mathrm{W}_{\mathrm{I}}$ & 1.8936 & 2.840 & 2.7770 & 2.9456 & 2.8193 & 2.9456 \\
\hline TDS $Q_{I} W_{I}$ & 0.0935 & 0.1010 & 0.1766 & 0.1523 & 0.1000 & 0.0731 \\
\hline $\mathrm{EC} \mathrm{Q}_{\mathrm{I}} \mathrm{W}_{\mathrm{I}}$ & 0.0846 & 0.0888 & 0.1377 & 0.1353 & 0.0781 & 0.0664 \\
\hline Hardness $\mathrm{Q}_{\mathrm{I}} \mathrm{W}_{\mathrm{I}}$ & 0.0393 & 0.0369 & 0.0315 & 0.0214 & 0.0423 & 0.0366 \\
\hline $\mathrm{DO} \mathrm{Q}_{\mathrm{I}} \mathrm{W}_{\mathrm{I}}$ & 5.6454 & 5.3101 & 5.4218 & 5.1983 & 4.9188 & 5.4218 \\
\hline Calcium $\mathrm{Q}_{\mathrm{I}} \mathrm{W}_{\mathrm{I}}$ & 0.1040 & 0.0875 & 0.2081 & 0.1019 & 0.1263 & 0.1406 \\
\hline Magnesium $\mathrm{Q}_{\mathrm{I}} \mathrm{W}_{\mathrm{I}}$ & 0.5020 & 0.5169 & 0.1132 & 0.0989 & 0.5759 & 0.3744 \\
\hline Sodium $\mathrm{Q}_{\mathrm{I}} \mathrm{W}_{\mathrm{I}}$ & 0.0546 & 0.0721 & 0.1086 & 0.1220 & 0.0721 & 0.0523 \\
\hline Bicarbonate $\mathrm{Q}_{\mathrm{I}} \mathrm{W}_{\mathrm{I}}$ & 0.2843 & 0.2106 & 0.3970 & 0.2897 & 0.3179 & 0.2562 \\
\hline Chlorides $\mathrm{Q}_{\mathrm{I}} \mathrm{W}_{\mathrm{I}}$ & 0.2586 & 0.2026 & 0.5503 & 0.1983 & 0.1639 & 0.2119 \\
\hline Sulphate $\mathrm{Q}_{\mathrm{I}} \mathrm{W}_{\mathrm{I}}$ & 0.0182 & 0.0340 & 0.1398 & 0.0742 & 0.0363 & 0.0102 \\
\hline Iron $\mathrm{Q}_{\mathrm{I}} \mathrm{W}_{\mathrm{I}}$ & 168.12 & 62.302 & 12.520 & 45.311 & 33.387 & 19.972 \\
\hline$\Sigma \mathrm{Q}_{\mathrm{I}} \mathrm{W}_{\mathrm{I}}$ & 177.09 & 69.546 & 22.58 & 54.648 & 42.637 & 29.56 \\
\hline WQI & 177.26 & 69.52 & 22.60 & 54.70 & 42.67 & 29.58 \\
\hline Water Quality & $\begin{array}{l}\text { Very } \\
\text { Poor }\end{array}$ & Poor & $\begin{array}{l}\text { Very } \\
\text { Good }\end{array}$ & Poor & Good & Good \\
\hline
\end{tabular}

Water quality is classified based on WQI value, 0-25 is very good water, 25-50 is good, 50-70 is poor water and greater than 70 is very poor. The higher value of WQI of GW-1 is found due to the presence of 
iron in the groundwater samples. Among all the of the water samples, the percentage (\%) of WQI categories Good (33\%), Very Good (17\%), Poor (33\%) and Very Poor (17\%) were observed (Fig.-4).

\section{WQI Categories of Samples}

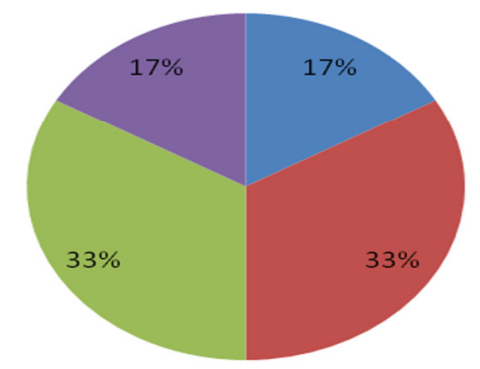

- Very Poor

- Poor

- Good

very Good

Fig.-4: WQI Categories of Groundwater Samples (\%)

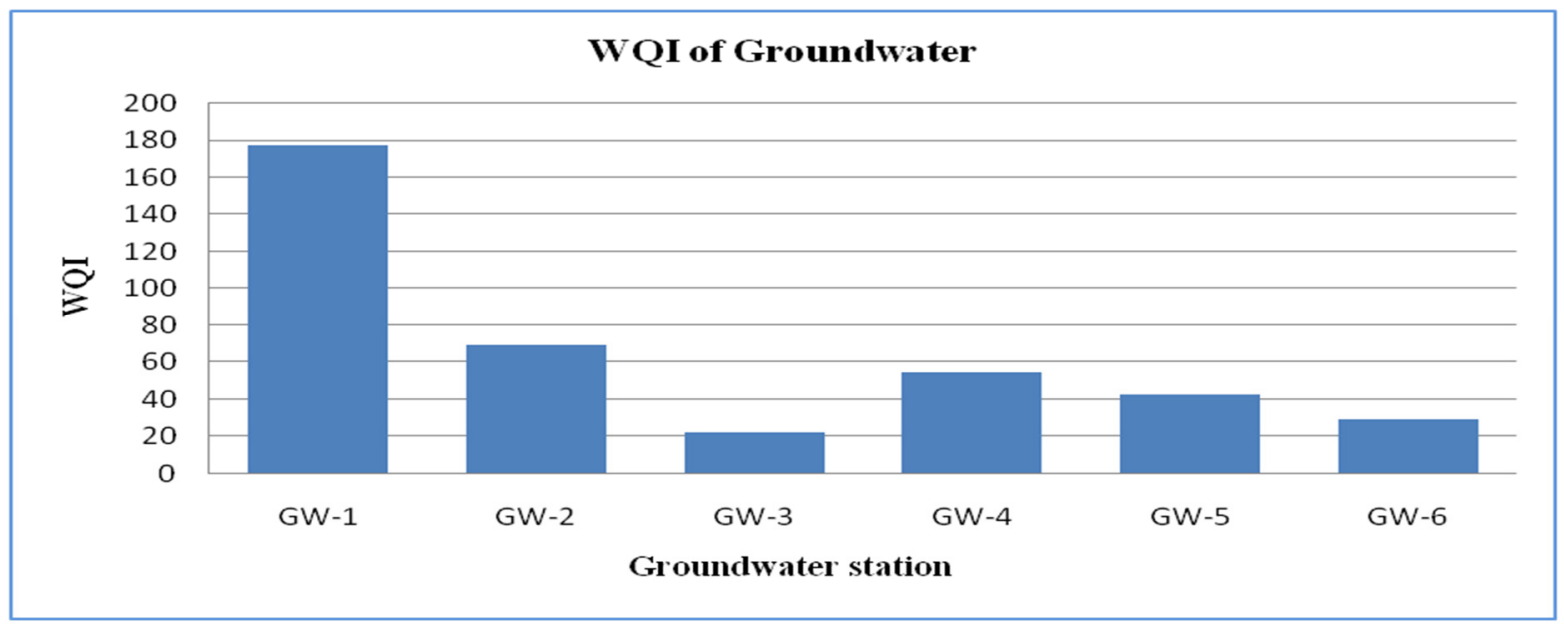

Fig.-5: Graphical Representation of WQI of Groundwater

CONCLUSION

On the basis of the above discussions, it may be concluded that the groundwater has polluted as indicated by WQI due to Coal Mining activities. The water quality analysis shows that $16.66 \%$ of water samples were found as a Very Good category, 33.33\% of water samples are a Good category and can be used for direct consumption while $33.33 \%$ of water samples are the Poor category and $16.66 \%$ in the Very Poor category. Water Quality Index of 50\% ground water samples shows that the water is not suitable for direct consumption. After treatment of that water, samples can be used for drinking purposes in the study area.

\section{ACKNOWLEDGMENT}

The authors are especially grateful to the Indian Institute of Technology, Banaras Hindu University, Varanasi for providing the technical support during the whole Research period

\section{REFERENCES}

1. Ranjana Agrawal, Rasayan J. Chem., 2(4), 969(2009).

2. Ram Bhoosan Prasad Singh, Amrita Singh and Sunil K. Choudhary, International Journal on Emerging Technologies, 5(2), 95(2014).

3. WHO, Guidelines for Drinking Water Quality, Geneva, Switzerland, (2011). 
4. APHA, AWWA, WEF. Washington DC, Standard Methods for the Examination of Water and Waste Water, 20th Ed. (1998).

5. Chanti Babu Patneedi and K. Durga Prasadu, Rasayan Journal of Chemistry, 8(1), 67(2015).

6. Raja Rao C S, Coalfields of India, Vol. III; Coal resources of Madhya Pradesh, Jammu and Kashmir; Bull. Geol. Surv. India, Series A, 45, 75(1983).

7. J.M. Sanchez-perez and M. Tremolieres, Journal of Hydrology, 270(1-2), 89 (2003).

8. H.L. Yadav, and A. Jamal, Rasayan J. Chem., 11(1), 46(2018).

9. Kannan K. Fundamental of Environmental Pollution, S. Chand \& Co. Ltd., New Delhi 1991.

10. K.M. Sharma, Rolli Pandey, Md. Umar Farooq and Mridul, Jain, Rasayan Journal of Chemistry, 8(1), 42(2015).

11. Prasoon Kumar Singh,Ashwani Kumar Tiwari and Mukesh Kumar Mahato, International Journal of ChemTech Research,5(5), 2351(2013).

12. WHO Guidelines for Drinking Water Quality, 2nd Ed., 1,188(1993).

13. M.Suresh Kumar, R.Sivakumar and M. Nagarajan, Rasayan Journal of Chemistry, 9(3), 454(2016).

14. S. Mitharwal, R. D. Yadav and R. C. Angasaria, Rasayan Journal of Chemistry, 2, 920(2009).

15. K. Sneka Lata, A. Jesu and M.S. Dheenadayalan, Rasayan Journal of Chemistry, 8(3), 380(2015).

16. P. Thamilarasu and R. Sharmila, Rasayan Journal of Chemistry, 8(1), 92(2015).

17. Durga Karthik, K. Vijayarekha and M. Sugany, Rasayan Journal of Chemistry, 8(4), 487(2015).

[RJC-4026/2018] 